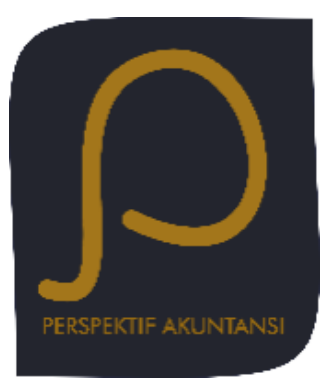

Perspektif Akuntansi

Volume 4 Nomor 2 (Juni 2021), hal. 121-144

ISSN: 2623-0194 (Print), 2623-0186 (Online)

Copyright(C The Authors(s). All Rights Reserved

Center for Accounting Development and Research (CARD)

Fakultas Ekonomika dan Bisnis,

Universitas Kristen Satya Wacana

DOI: https://doi.org/10.24246/persi.vXiX.p121-144

http://ejournal.uksw.edu/persi

\title{
Analisis Cost-Benefit Penerapan PSAK Berbasis IFRS
}

\author{
Yoko Cingsy Karundeng \\ RSUD Manembo-Nembo, Bitung \\ Ari Budi Kristanto ${ }^{1}$ \\ Universitas Kristen Satya Wacana, Salatiga
}

Received

05/04/2021

Abstract. The purpose of IFRS convergence is to increase the

Revised

$23 / 05 / 2021$

Accepted

25/05/2021 quality of accounting information on financial statements. However, it takes cost to implement the latest PSAK which is in accordance with IFRS. In addition to cost, it is expected that the benefits obtained will be greater. This study aims to analyze the cost-benefits that arise due to the application of PSAK which based on IFRS. Public companies registered on the Indonesia Stock Exchange in 2015 and 2016 are the object of this study. The research sample was selected using purposive sampling method with specified criteria. Cost measurement uses score weights based on change categories due to the use of new PSAK, such as rerecognition, re-measurement or reclassification. While the benefits of IFRS are measured by the relevance of the value proxied by the determination coefficient of the regression function in the price model. Furthermore, based on the cost-benefit ratio analysis, the results show that in general the benefits of applying PSAK based on IFRS in Indonesia are higher than the cost. Only a small group of companies found that the cost of implementing PSAK was not comparable to the benefits.

Keywords: IFRS convergence, cost, benefit, relevance

1 ari.kristanto@uksw.edu 


\begin{abstract}
Abstrak. Tujuan dari konvergensi IFRS adalah untuk meningkatkan kualitas informasi akuntansi laporan keuangan. Namun, dibutuhkan upaya (cost) untuk mengimplementasikan PSAK terbaru yang sudah sesuai dengan IFRS. Selain cost, diharapkan manfaat (benefit) yang diperoleh lebih besar Penelitian ini bertujuan untuk menganalisis cost-benefit yang timbul akibat penerapan PSAK berbasis IFRS. Perusahaaanperusahaan publik yang terdaftar di Bursa Efek Indonesia pada tahun 2015 dan 2016 merupakan objek penelitian ini. Sampel penelitian dipilih menggunakan metode purposive sampling dengan kriteria yang telah ditentukan. Pengukuran cost menggunakan bobot skor berdasarkan kategori perubahan akibat penggunaan PSAK yang baru, seperti pengakuan ulang, pengukuran ulang atau klasifikasi ulang. Sedangkan manfaat dari penggunaan IFRS diukur oleh relevansi nilai yang diproksikan oleh koefisien determinasi fungsi regresi pada model harga (price model). Selanjutnya berdasarkan analisis cost-benefit ratio, diperoleh hasil bahwa secara umum benefit penerapan PSAK berbasis IFRS di Indonesia lebih tinggi dari costnya. Hanya sebagian kecil kelompok perusahaan yang ditemukan bahwa cost penerapan PSAK lebih rendah dari benefit yang diperoleh dari implementasinya.
\end{abstract}

Kata kunci: konvergensi IFRS, cost, benefit, relevansi nilai

\title{
Pendahuluan
}

Penerapan Standar Akuntansi yang berkualitas menjadi sangat penting untuk memastikan penyusunan dan penyajian laporan keuangan akan menghasilkan informasi akuntansi yang berkualitas pula (Qomariah dan Marsono 2013). International Accounting Standards Board (IASB) merupakan badan pembuat standar pelaporan keuangan yang dibentuk dengan tujuan untuk menghasilkan standar pelaporan keuangan yang berkualitas tinggi (Cahyonowati dan Ratmono 2012). IASB menerbitkan Standar Pelaporan Keuangan Internasional (International Financial Reporting Standards/IFRS) yang bertujuan untuk memastikan bahwa laporan keuangan perusahaan memiliki kualitas informasi akuntansi yang tinggi. Pada saat IFRS mulai diterapkan oleh negara-negara di Uni Eropa dan sebagian besar negaranegara di Asia Pasifik, muncul banyak perdebatan mengenai cost-benefit yang timbul saat menerapkan IFRS itu sendiri (Taylor 2009). Dengan kata lain, dibutuhkan upaya atau pengorbanan saat perusahaan ingin memastikan bahwa laporan keuangannya mengandung informasi yang berkualitas tinggi. Di Indonesia sendiri, Ikatan Akuntan Indonesia (IAI) menyatakan bahwa konvergensi telah dilakukan sejak tahun 2008 yang diawali dengan tahap adopsi, tahun 2011 tahap persiapan dan tahun 2012 merupakan tahap implementasi (Lestari 2013). 
Pawsey (2007) dalam Taylor (2009) menemukan bahwa cost muncul saat pertama kali menerapkan IFRS berupa biaya pelatihan staf yang timbul akibat kurangnya keahlian yang memadai serta cost berupa biaya lembur staf atau biaya mempekerjakan staf tambahan. Biaya-biaya tersebut muncul akibat laporan keuangan yang mengalami penyesuaian saat menerapkan IFRS. Dengan kata lain, cost akan muncul apabila ada upaya atau pengorbanan yang dilakukan perusahaan saat menerapkan IFRS. Pernyataan tersebut didukung dengan hasil penelitian sebelumnya oleh Taylor (2009) bahwa cost dan penerapan IFRS akan semakin tinggi, jika upaya atau pengorbanan menerapkan IFRS tinggi. Artinya, cost yang dihasilkan dari penerapan IFRS berbanding lurus dengan upaya atau pengorbanan saat menerapkan IFRS.

Selain cost, diharapkan diperoleh benefit yang lebih besar sebagai hasil dari penerapan IFRS. Kualitas informasi akuntansi yang tinggi merupakan hasil dari penerapan IFRS (Taylor 2009). Sugiarti (2017) yang menyatakan bahwa dengan adanya penerapan IFRS diharapkan terdapat salah satu kualitas utama dalam informasi akuntansi, yaitu relevansi. Beberapa literatur seperti Taylor (2009), Cahyonowati dan Ratmono (2012), Kargin (2013) serta Suprihatin dan Tresnaningsih (2013), menunjukan bahwa salah satu ukuran untuk menguji (proksi) kualitas suatu informasi akuntansi saat menerapkan IFRS adalah relevansi nilai. Selanjutnya Suprihatin dan Tresnaningsih (2013) mengatakan bahwa kualitas informasi akuntansi yang tinggi mempunyai relevansi nilai laba bersih dan nilai buku ekuitas yang tinggi. Dengan kata lain, kualitas informasi akuntansi memiliki pengaruh positif terhadap relevansi nilai laba bersih dan nilai buku ekuitas. Pernyataan tersebut dibuktikan dengan hasil penelitian Suprihatin dan Tresnaningsih (2013) yang menunjukan bahwa relevansi nilai laba bersih dan nilai buku ekuitas meningkat setelah menerapkan IFRS pada tahap lanjutan atau tahap implementasi. Semakin banyak standar berdasarkan IFRS yang diimplementasikan pada PSAK, semakin tinggi relevansi nilai yang diharapkan oleh perusahaan di Indonesia (Suprihatin dan Tresnaningsih 2013). Dengan demikian konvergensi IFRS diharapkan memiliki dampak yang signifikan pada perusahaan di Indonesia, khususnya terkait dengan relevansi nilai informasi akuntansi.

Penelitian sebelumnya membandingkan cost-benefit dari konvergensi IFRS berdasarkan tingkat penyesuaian standar akuntansi negaranya terhadap IFRS. Penelitian sebelumnya oleh Taylor (2009) yang berkonsentrasi pada perusahaan publik di Inggris, Hong Kong dan Singapura menemukan bahwa biaya (cost) penyesuaian tertinggi terdapat pada negara Inggris karena standar akuntansi keuangan negaranya yang paling tidak konvergen dengan IFRS. Namun di masingmasing negara tersebut konvergensi IFRS menghasilkan benefit yang tidak signifikan bagi pengguna laporan keuangan dalam hal memberikan informasi yang relevan.

Di Indonesia sendiri, konvergensi IFRS dilakukan secara bertahap yang dimulai sejak tahun 2008 dengan target penerapan IFRS telah diimplementasikan penuh pada tahun 2012. Beberapa penelitian terdahulu menemukan bahwa konvergensi IFRS di Indonesia memiliki beberapa manfaat, seperti komparabilitas laporan keuangan, 
peningkatan arus investasi internasional, mengurangi biaya modal, peningkatan relevansi informasi, serta peningkatan kualitas laporan keuangan (Kristanto, 2015; Suyatmini \& Sheilla, 2014). Pada umumnya di jurnal-jurnal penelitian sebelumnya hanya membahas tentang manfaat dari penerapan PSAK berbasis IFRS, masih kurang penelitian yang membahas tentang cost dari penerapan PSAK berbasis IFRS. Dengan demikian, kajian ini bertujuan untuk menganalisis cost-benefit yang timbul akibat penerapan PSAK berbasis IFRS.

Adapun rumusan persoalan penelitian meliputi: pertama, seberapa cost atau upaya (effort) perusahaan-perusahaan publik saat menerapkan PSAK berbasis IFRS? Kedua, seberapa benefit berupa relevansi nilai informasi akuntansi dari penerapan PSAK berbasis IFRS? Ketiga, bagaimana perbandingan cost-benefit penerapan PSAK berbasis IFRS pada perusahaan-perusahaan publik di Indonesia? Pada penelitian kali ini, perusahaan diklasifikasikan berdasarkan ukuran perusahaan dan jenis industri, yaitu perusahaan-perusahaan publik pada sembilan kelompok industri di BEI. Penelitian sebelumnya oleh Taylor (2009) menganalisis cost-benefit pada perusahaan-perusahaan di Inggris, Hongkong dan Singapura secara umum, belum lebih spesifik mengidentifikasi ukuran dan jenis industrinya. Analisis berbasis ukuran perusahaan dan jenis industri perlu untuk diperhatikan, mengingat perusahaan besar memiliki sumber daya yang lebih baik untuk mengimplementasikan PSAK berbasis IFRS dibanding perusahaan kecil. Demikian pula, jenis industri yang berbeda dengan ciri model bisnis masing-masing, akan memberikan variasi dalam implementasi PSAK berbasis IFRS revisi terbaru. Hasil penelitian ini diharapkan memberikan manfaat bagi pembaca untuk menambah literatur tentang efek penerapan PSAK berbasis IFRS di Indonesia, khusus dalam hal biaya dan manfaatnya saja. Bagi pembuat standar dan akademisi, hasil penelitian ini dapat digunakan untuk untuk mengevaluasi implementasi penerapan PSAK berbasis IFRS di Indonesia.

\section{Telaah Pustaka}

\section{Konvergensi IFRS di Indonesia}

Utami, Suhardjanto dan Hartoko (2012) menyatakan bahwa konvergensi berarti proses meningkatkan kesesuaian praktik akuntansi. Jika dikaitkan dengan IFRS, konvergensi dapat berarti proses penyesuaian Standar Akuntansi Keuangan (SAK) dengan dasar IFRS. Hal tersebut serupa dengan pernyataan Cahyati (2011) bahwa konvergensi berarti membuat standar akuntansi keuangan suatu negara menjadi sama seperti IFRS. Negara Indonesia menggunakan PSAK (Pernyataan Standar Akuntansi Keuangan) sebagai standar akuntansi keuangannya. Oleh karenanya konvergensi IFRS di Indonesia merupakan penyesuaian PSAK terhadap IFRS.

Dalam menerapkan konvergensi IFRS, Indonesia menerapkannya secara bertahap (Suprihatin dan Tresnaningsih 2013). Sejalan dengan Lestari (2013), penelitiannya menyatakan bahwa konvergensi dimulai sejak tahun 2008 secara bertahap dengan target penerapan IFRS dapat diselesaikan pada tahun 2012. Proses konvergensi IFRS terbagi ke dalam tiga tahap: (1) tahap adopsi pada tahun 2008-2010, dilakukan adopsi terhadap seluruh IFRS, sebagai awalannya disiapkan infrastruktur yang 
diperlukan dan dilakukan evaluasi terhadap dampak adopsi terhadap PSAK yang digunakan; (2) tahap persiapan akhir pada tahun 2011, diselesaikan persiapan infrastruktur yang diperlukan dan secara bertahap diterapkan PSAK berdasarkan IFRS; dan (3) tahap implementasi di tahun 2012, terus dilakukan penerapan PSAK berdasarkan IFRS dan dilakukan evaluasi terhadap dampak penerapan PSAK secara menyeluruh.

Berikut ini merupakan Tabel 1 mengenai perubahan PSAK setelah Konvergensi IFRS.

Tabel 1: Perubahan PSAK Setelah Konvergensi IFRS Tiap Akun Pelaporan

\begin{tabular}{c}
\hline Pengukuran Ulang \\
\hline Tidak lagi mengatur \\
pengukuran pembayaran \\
berbasis saham untuk \\
karyawan atau pihak lain. \\
Transaksi pembayaran \\
harus diselesaikan \\
dengan tunai, aset lain \\
atau instrumen ekuitas \\
entitas. \\
\\
Pengukuran aset dan \\
liabilitas yang diambil \\
alih hanya menggunakan \\
purchase method, serta \\
telah menggunakan nilai \\
wajar seperti PSAK lain.
\end{tabular}
Share-based payment

Mensyaratkan entitas

untuk mengakui dampak

transaksi pembayaran

berbasis saham dalam

laporan keuangan (laporan

laba rugi dan laporan posisi keuangan).

Business combination

Menggunakan purchase method yang mendorong perlunya pengakuan atas goodwill.

Events after balance sheet date

\begin{tabular}{cc}
\hline & $\begin{array}{c}\text { Merevisi istilah event } \\
\text { after balance sheet date } \\
\text { (peristiwa setelah tanggal } \\
\text { neraca) direvisi menjadi } \\
\text { event after reporting } \\
\text { period (peristiwa setelah } \\
\text { periode pelaporan). }\end{array}$ \\
& $\begin{array}{c}\text { Income tax / deferred tax } \\
\text { Mengatur tentang beda } \\
\text { temporer antara basis } \\
\text { pajak dengan basis } \\
\text { komersil yang dijadikan } \\
\text { basis dalam mengakui } \\
\text { kewajiban pajak } \\
\text { tangguhan. } \\
\text { Leases } \\
\text { Mengakui elemen tanah } \\
\text { dan bangunan dalam } \\
\text { perjanjian sewa sebagai }\end{array} \quad$ Elemen tanah dan \\
\hline
\end{tabular}




\begin{tabular}{|c|c|c|}
\hline Pengukuran Ulang & Pengakuan Ulang & Klasifikasi Ulang \\
\hline & $\begin{array}{c}\text { sewa pembiayaan atau } \\
\text { sewa operasi. } \\
\text { Employee benefits/ obligation }\end{array}$ & $\begin{array}{l}\text { perjanjian sewa dinilai } \\
\text { terpisah klasifikasinya. }\end{array}$ \\
\hline & $\begin{array}{l}\text { Mengakui dalam laporan } \\
\text { laba rugi jumlah neto } \\
\text { imbalan sebagai beban } \\
\text { atau penghasilan. } \\
\text { Foreign exchange change }\end{array}$ & \\
\hline & $\begin{array}{l}\text { Mengakui selisih kurs } \\
\text { dalam laporan laba rugi } \\
\text { periode berjalan. } \\
\text { Intangible assets }\end{array}$ & \\
\hline & $\begin{array}{c}\text { Biaya ditangguhkan } \\
\text { sampai aset dapat } \\
\text { digunakan sesuai } \\
\text { keinginan manajemen dan } \\
\text { kerugian awal operasi } \\
\text { tidak termasuk jumlah } \\
\text { tercatat aset tak berwujud. } \\
\text { Serta adanya pengakuan } \\
\text { gain/loss. }\end{array}$ & $\begin{array}{c}\text { Keuntungan dari } \\
\text { pelepasan aset tak } \\
\text { berwujud tidak } \\
\text { diklasifikasikan sebagai } \\
\text { revenue melainkan } \\
\text { sebagai gain/loss. Serta } \\
\text { setiap aset tak berwujud } \\
\text { yang didapat tidak dengan } \\
\text { IFRS harus diklasifikasi } \\
\text { ulang. }\end{array}$ \\
\hline & Property plant and equipment & \\
\hline & Financial instruments & $\begin{array}{c}\text { Mengubah aset tetap yang } \\
\text { tersedia untuk dijual } \\
\text { menjadi aset tidak lancar } \\
\text { yang dimiliki untuk dijual. }\end{array}$ \\
\hline $\begin{array}{l}\text { Reklasifikasi aset } \\
\text { keuangan diukur pada } \\
\text { nilai wajar melalui laba } \\
\text { rugi ke pinjaman yang } \\
\text { diberikan dan piutang. }\end{array}$ & $\begin{array}{l}\text { Menghentikan pengakuan } \\
\text { aset keuangan, jika dan } \\
\text { hanya jika: } \\
\text { Hak kontraktual atas arus } \\
\text { kas yang berasal dari aset } \\
\text { keuangan tersebut } \\
\text { berakhir; atau } \\
\text { Entitas mentransfer aset } \\
\text { keuangan, dan transfer } \\
\text { tersebut memenuhi } \\
\text { kriteria penghentian } \\
\text { pengakuan } \\
\text { Investment property }\end{array}$ & $\begin{array}{l}\text { Aset keuangan sebagai } \\
\text { tersedia untuk dijual } \\
\text { dapat diklasifikasi ke } \\
\text { pinjaman yang diberikan } \\
\text { dan piutang, serta } \\
\text { puttable instruments dan } \\
\text { instrumen dengan } \\
\text { kewajiban menyerahkan } \\
\text { bagian aset neto secara } \\
\text { pro rata saat likuidasi } \\
\text { diklasifikasikan sebagai } \\
\text { instrumen ekuitas. }\end{array}$ \\
\hline $\begin{array}{l}\text { Mengizinkan penggunaan } \\
\text { metode nilai wajar dalam } \\
\text { mengukur properti } \\
\text { investasi. }\end{array}$ & & $\begin{array}{l}\text { Menyajikan secara khusus } \\
\text { properti investasi. }\end{array}$ \\
\hline \multicolumn{3}{|c|}{ Investments in associates and joint ventures } \\
\hline & & $\begin{array}{c}\text { Sisa bagian apapun dari } \\
\text { investasi ini yang belum } \\
\text { diklasifikasikan sebagai } \\
\text { dimiliki untuk dijual } \\
\text { dicatat dengan } \\
\text { menggunakan metode } \\
\text { ekuitas sampai pelepasan } \\
\text { bagian yang }\end{array}$ \\
\hline
\end{tabular}




\begin{tabular}{|c|c|c|}
\hline Pengukuran Ulang & Pengakuan Ulang & Klasifikasi Ulang \\
\hline & & $\begin{array}{l}\text { diklasifikasikan sebagai } \\
\text { dimiliki untuk dijual } \\
\text { terjadi. Setelah pelepasan } \\
\text { terjadi entitas mencatat } \\
\text { bagian yang tersisa dalam } \\
\text { entitas asosiasi atau } \\
\text { ventura bersama sesuai } \\
\text { dengan PSAK 55, kecuali } \\
\text { bagian yang tersisa tetap } \\
\text { menjadi entitas asosiasi } \\
\text { atau ventura bersama. }\end{array}$ \\
\hline \multicolumn{3}{|c|}{ Inventories } \\
\hline & Cash and equivalents & $\begin{array}{c}\text { Aset biologis mengalami } 3 \\
\text { tahap klasifikasi, yaitu } \\
\text { tahap tanaman belum } \\
\text { menghasilkan, tanaman } \\
\text { menghasilkan dan } \\
\text { persediaan. }\end{array}$ \\
\hline & $\begin{array}{l}\text { Provisions,contingent } \\
\text { liabilities and contingent } \\
\text { assets }\end{array}$ & $\begin{array}{l}\text { Mengklasifikasikan arus } \\
\text { kas menjadi arus kas } \\
\text { investasi, arus kas operasi } \\
\text { dan arus kas pendanaan. } \\
\text { Tidak lagi mengakui } \\
\text { kewajiban diestimasi dan } \\
\text { kontinjensi yang timbul } \\
\text { dari instrumen keuangan } \\
\text { yang dicatat dengan nilai } \\
\text { wajar, dan kontrak } \\
\text { dengan pemegang polis } \\
\text { bagi entitas asuransi. }\end{array}$ \\
\hline \multicolumn{3}{|c|}{ Loans and borrowings } \\
\hline & & $\begin{array}{c}\text { Diklasifikasikan sebagai } \\
\text { beban untuk biaya } \\
\text { pinjaman yang } \\
\text { menggantikan inflasi. }\end{array}$ \\
\hline
\end{tabular}

Sumber: Dirangkum dari ED PSAK

\section{Cost Penerapan PSAK berbasis IFRS}

Cost merupakan upaya atau pengorbanan sejumlah nilai untuk mencapai suatu tujuan dan diharapkan pengorbanan tersebut menghasilkan manfaat di masa yang akan datang (Wibowo 2012). Dalam konteks penelitian ini, cost implementasi IFRS merujuk pada pengorbanan yang dibuat oleh perusahaan sebagai konsekuensi dari penggunaan standar akuntansi baru berbasis IFRS, karena implementasi tersebut menuntut perubahan dalam pengakuan, pengukuran maupun pengungkapan suatu informasi. Proses menyesuaikan SAK nasional menjadi SAK internasional atau proses transisi ke IFRS memerlukan cost yang mencakup proses penyesuaian atau proses transisi itu sendiri (Taylor 2009). Lebih lanjut Taylor (2009) juga menyebutkan bahwa cost saat perusahaan pertama kali menerapkan IFRS tersebut berupa biaya pelatihan staf akibat kurangnya keahlian yang memadai dan cost berupa biaya lembur 
staf atau cost akibat mempekerjakan staf tambahan. Lebih tepatnya untuk menggambarkan biaya yang mendasari perusahaan untuk melakukan transisi dari Generally Accepted Accounting Principles (GAAP) ke IFRS, seperti biaya pelatihan penyusunan laporan keuangan, biaya modifikasi sistem akuntansi perusahaan dan biaya layanan jasa penilai (Taylor 2009).

Sejak tahun 2008, Indonesia memutuskan mengubah SAK sebelumnya yang menerapkan GAAP menjadi SAK yang menggunakan IFRS. Dalam penelitian Juanda (2014), terdapat beberapa hal utama yang diatur dalam SAK berdasarkan IFRS. Pertama, pengukuran atau measurement yang berguna untuk menetapkan nilai dari suatu elemen laporan keuangan baik pada saat terjadinya transaksi keuangan maupun pada saat penyajian laporan keuangan yaitu pada tanggal neraca. Yang berikutnya adalah pengakuan atau recognition, yang berguna untuk mengakui elemen laporan keuangan sehingga elemen tersebut boleh disajikan dalam laporan keuangan. Kemudian yang terakhir adalah penyajian atau presentation laporan keuangan, yang berguna untuk menentukan jenis informasi atau menggolongkannya atau classification dan bagaimana informasi tersebut akan disajikan. Taylor (2009) kemudian menyebutkan bahwa perubahan pelaporan keuangan setelah penerapan IFRS melibatkan pengukuran ulang atau re-measurement, pengakuan ulang atau derecognition, serta pengakuan baru atau new recognition atau klasifikasi ulang atau reclassification.

PSAK sebelum konvergensi IFRS mengukur setiap transaksinya menggunakan prinsip historical cost, sedangkan IFRS lebih mengutamakan menggunakan nilai wajar atau fair value (Lestari 2013). Sejalan dengan yang dinyatakan Taylor (2009) bahwa pengukuran kembali atau re-measurement akibat transisi ke IFRS berkemungkinan rumit dan mahal karena biasanya melibatkan penggunaan nilai wajar dan biasanya pengukuran ini tidak digunakan. Hal ini tentunya akan menimbulkan cost pada saat pertama kali mengkonvergensi IFRS, seperti cost yang mengakibatkan penggunaan jasa penilai (Taylor 2009).

Selain hal pengukuran, pengakuan juga menjadi hal penting yang diatur dalam SAK berdasarkan IFRS. Secara prinsip, terdapat kesamaan antara pengakuan pendapatan dan pengakuan aktiva antara standar akuntansi keuangan sebelum dan setelah konvergensi IFRS (Lestari 2013). Hal ini mungkin tidak akan serumit pengukuran kembali, saat ada perbedaan pengakuan, yang melibatkan beberapa modifikasi pada bagian akun pada laporan keuangan dan sistem informasi akuntansi (Taylor 2009). Kemungkinan, hal tersebut akan menimbulkan cost berupa biaya lembur staf atau biaya mempekerjakan staf tambahan untuk memodifikasi laporan keuangan atau sistem informasi akuntansi perusahaan.

Hal penting yang terakhir, yaitu penyajian laporan keuangan. Terdapat perbedaan dalam penyajian laporan keuangan antara PSAK sebelum dan setelah konvergensi IFRS terutama pada komponen laporan keuangannya. Berikut adalah perbedaan komponen laporan keuangan dalam PSAK sebelum dan setelah konvergensi IFRS menurut penelitian Lestari (2013) dan Utami (2006): (1) neraca menjadi laporan 
posisi keuangan; (2) laporan laba rugi menjadi laba rugi komprehensif; (3) terdapat tambahan komponen, yaitu laporan posisi keuangan awal pada PSAK berdasarkan IFRS. Taylor (2009) menyebutkan dalam penelitiannya bahwa pengklasifikasian ulang (re-classification) merupakan hal yang paling mudah, lebih mudah dari pengakuan ulang dan pengakuan baru karena berupa peralihan akun yang relatif mudah. Cost yang akan muncul kemungkinan berupa biaya pelatihan staf (Taylor 2009). Hal tersebut dikarenakan terjadinya perubahan pada penyajian laporan keuangan saat pertama kali mengkonvergensi IFRS sehingga dibutuhkan staf yang memadai. Cost juga dapat berupa biaya lembur staf atau cost akibat mempekerjakan staf tambahan (Taylor 2009).

\section{Benefit dari Penerapan PSAK Berbasis IFRS Berupa Relevansi Nilai Informasi Akuntansi}

Manfaat merupakan hasil yang diperoleh atau diterima dari suatu pengorbanan (Wibowo 2012). Dalam konteks penelitian ini, manfaat implementasi PSAK berbasis IFRS merujuk pada hasil atau manfaat yang diperoleh perusahaan setelah menggunakan standar akuntansi baru. Sejalan dengan tujuan IFRS, yaitu meningkatkan kualitas informasi akuntansi pada laporan keuangan, maka manfaat dari konvergensi IFRS sendiri ialah menghasilkan laporan keuangan yang mengandung informasi akuntansi yang berkualitas. Dengan adanya konvergensi IFRS diharapkan terdapat salah satu kualitas utama dalam informasi akuntansi, yaitu relevansi (Sugiarti 2017). Beberapa literatur seperti Taylor (2009), Cahyonowati dan Ratmono (2012), Kargin (2013) serta Suprihatin dan Tresnaningsih (2013), menyatakan bahwa proksi kualitas informasi akuntansi saat konvergensi IFRS adalah relevansi nilai. Kargin (2013) mendefinisikan relevansi nilai informasi akuntansi adalah kemampuan informasi yang diungkapkan oleh laporan keuangan untuk menangkap dan merangkum nilai perusahaan. Hal tersebut serupa dengan pernyataan Cahyonowati dan Ratmono (2012) yang mendeskripsikan relevansi nilai informasi akuntansi sebagai kemampuan angka-angka akuntansi untuk merangkum informasi yang mendasari harga saham guna pengambilan keputusan oleh investor.

Hasil penelitian Suprihatin dan Tresnaningsih (2013) menunjukan bahwa tidak ada bukti peningkatan relevansi nilai dari nilai buku ekuitas pada tahap awal penerapan IFRS namun terbukti meningkatkan relevansi nilai dari laba bersih terhadap harga saham. Hal tersebut didukung oleh hasil penelitian Cahyonowati dan Ratmono (2012) yang menunjukan bahwa pada tahap awal setelah penerapan IFRS (2008-2011) hanya terbukti meningkatkan relevansi nilai untuk informasi laba bersih terhadap harga saham. Suprihatin dan Tresnaningsih (2013) berpendapat bahwa mungkin pada tahap awal penerapan IFRS masih sangat terbatasnya PSAK berdasarkan IFRS yang berlaku efektif, sehingga investor menilai belum ada peningkatan kualitas angka nilai buku ekuitas. Namun, investor menilai telah ada peningkatan kualitas laba. Suprihatin dan Tresnaningsih (2013) juga menyatakan dalam penelitiannya bahwa penerapan IFRS pada tahap lanjutan terbukti meningkatkan relevansi nilai dari nilai buku ekuitas dan laba bersih terhadap harga saham. Hal tersebut menunjukan bahwa 
investor telah mempersepsikan pemberlakuan lebih banyak PSAK berdasarkan IFRS sebagai adanya peningkatan kualitas angka nilai buku ekuitas dan angka laba.

\section{Metoda}

\section{Populasi dan Sampel}

Studi ini merupakan penelitian deskriptif dengan populasi seluruh perusahaan yang terdaftar di Bursa Efek Indonesia (BEI) pada tahun 2015 dan 2016. Tahun 2015 dan 2016 dipilih karena tahun tersebut PSAK Indonesia sudah konvergen secara penuh terhadap IFRS dan sudah diimplementasikan. Perusahaan yang akan menjadi sampel penelitian dipilih dengan menggunakan metode purposive sampling, sehingga pemilihan sampel menggunakan kriteria atau pertimbangan-pertimbangan tertentu yang disesuaikan dengan tujuan maupun masalah penelitian. Kriteria-kriteria yang dimaksud adalah sebagai berikut: terdaftar dalam Bursa Efek Indonesia (BEI) tahun 2015 dan 2016, menerbitkan laporan keuangan selama tahun 2015-2016 berturutturut, memiliki data lengkap terkait dengan variabel-variabel yang digunakan di dalam penelitian ini.

\section{Jenis dan Sumber Data}

Jenis data yang digunakan dalam penelitian ini adalah data sekunder, berupa informasi PSAK 8, PSAK 46, PSAK 30, PSAK 10, PSAK 50/55, PSAK14, PSAK 2, PSAK 26, PSAK 53, PSAK 22, PSAK 24, PSAK 19, PSAK 16, PSAK 13, PSAK 15, PSAK 57 serta book value of equity, earnings dan operating cash flow yang dilaporkan pada laporan keuangan tahunan perusahaan. Selain dari laporan keuangan tahunan perusahaan yang terdaftar di BEI pada tahun 2015 dan 2016 yang diperoleh dari website Bursa Efek Indonesia, informasi juga diperoleh dari website Yahoo Finance berupa closing price company's share dan jumlah share. Variabel yang digunakan penelitian ini adalah cost dan benefit dari penerapan PSAK berbasis IFRS.

\section{Cost dari penerapan PSAK berbasis IFRS}

Cost akan muncul apabila ada upaya atau pengorbanan yang dilakukan perusahaan saat menerapkan IFRS. Penelitian ini akan memberi gambaran seberapa cost, upaya atau pengorbanan perusahaan saat menerapkan PSAK berbasis IFRS. Taylor (2009) dalam penelitiannya menyebutkan bahwa perubahan pelaporan keuangan setelah menerapkan IFRS melibatkan pengukuran ulang, pengakuan ulang atau pengakuan baru atau klasifikasi ulang. Pengukuran ulang merupakan hal paling rumit dan mahal, pengakuan ulang atau pengakuan baru mungkin kurang rumit dan mahal sedangkan klasifikasi ulang menjadi hal yang paling tidak rumit dan mahal (Taylor 2009). Variabel ini menggunakan skala pengukuran interval, yang menyajikan skema pembobotan dari yang paling rumit dan mahal hingga paling tidak rumit dan mahal untuk mencerminkan biaya masing-masing dalam proses konvergensi IFRS. Untuk pembobotannya sendiri, diberikan bobot skor 3 untuk pengukuran ulang (re- 
measurement), bobot skor 2 untuk pengakuan ulang (de-recognition)/pengakuan baru (new recognition) dan bobot skor 1 untuk klasifikasi ulang (re-classification).

Penilaian cost akan dibuat rasio antara bobot skor pada suatu perusahaan dengan total bobot skor, yaitu $\frac{\text { bobot skor perusahaan }}{40}=\%$

Tabel 1: Skor Pembobotan Cost Akun Laporan Keuangan Setelah Konvergensi

\begin{tabular}{|c|c|c|c|c|c|c|}
\hline Akun & PSAK & $\begin{array}{l}\text { Tahun } \\
\text { Efektif }\end{array}$ & $\begin{array}{c}\text { Pengukur } \\
\text { an ulang } \\
\text { (bobot } \\
\text { skor }=3 \text { ) }\end{array}$ & $\begin{array}{c}\begin{array}{c}\text { Pengakua } \\
\text { n ulang }\end{array} \\
\text { (bobot } \\
\text { skor }=2)\end{array}$ & $\begin{array}{c}\text { Klasifikasi } \\
\text { ulang }\end{array}$ & $\begin{array}{l}\text { Total } \\
\text { bobot } \\
\text { skor }\end{array}$ \\
\hline $\begin{array}{c}\text { Share-based } \\
\text { payment }\end{array}$ & 53 & 2016 & $\mathrm{X}$ & $\mathrm{X}$ & & 5 \\
\hline $\begin{array}{l}\text { Business } \\
\text { combination } \\
\text { (Goodwill) }\end{array}$ & 22 & 2016 & $\mathrm{X}$ & $X$ & & 5 \\
\hline $\begin{array}{c}\text { Events after } \\
\text { balance sheet } \\
\text { date }\end{array}$ & 8 & 2015 & & & $\mathrm{X}$ & 1 \\
\hline $\begin{array}{c}\text { Income } \\
\text { tax/deferred tax }\end{array}$ & 46 & 2015 & & $\mathrm{X}$ & & 2 \\
\hline Leases & 30 & 2015 & & $\mathrm{X}$ & $\mathrm{X}$ & 3 \\
\hline $\begin{array}{c}\text { Employee } \\
\text { benefits/obligati } \\
\text { ons }\end{array}$ & 24 & 2016 & & $\mathrm{X}$ & & 2 \\
\hline $\begin{array}{l}\text { Foreign exchange } \\
\text { changes }\end{array}$ & 10 & 2015 & & X & & 2 \\
\hline Intangible assets & 19 & 2016 & & $X$ & $\mathrm{X}$ & 3 \\
\hline $\begin{array}{l}\text { Property, plant } \\
\text { and equipment }\end{array}$ & 16 & 2016 & & & $\mathrm{X}$ & 1 \\
\hline $\begin{array}{l}\text { Financial } \\
\text { instruments }\end{array}$ & 50,55 & 2015 & $\mathrm{X}$ & $\mathrm{X}$ & $\mathrm{X}$ & 6 \\
\hline $\begin{array}{l}\text { Investment } \\
\text { property }\end{array}$ & 13 & 2016 & $\mathrm{X}$ & & $\mathrm{X}$ & 4 \\
\hline $\begin{array}{l}\text { Investments in } \\
\text { associstes and } \\
\text { joint ventures }\end{array}$ & 15 & 2016 & & & $\mathrm{X}$ & 1 \\
\hline Inventories & 14 & 2015 & & & $\mathrm{X}$ & 1 \\
\hline $\begin{array}{l}\text { Cash and } \\
\text { equivalents }\end{array}$ & 2 & 2015 & & & $\mathrm{X}$ & 1 \\
\hline $\begin{array}{l}\text { Loans and } \\
\text { borrowings }\end{array}$ & 26 & 2015 & & & $\mathrm{X}$ & 1 \\
\hline $\begin{array}{l}\text { Provisions,contin } \\
\text { gent liabilities } \\
\text { and contingent } \\
\text { assets }\end{array}$ & 57 & 2016 & & X & & 2 \\
\hline
\end{tabular}

Total bobot skor 40

Sumber: Didasarkan pada Taylor (2009) yang Dimodifikasi

Benefit dari penerapan PSAK berbasis IFRS berupa Relevansi Nilai Informasi Akuntansi 
Dengan adanya konvergensi IFRS diharapkan laporan keuangan perusahaan meningkat kualitasnya, salah satunya ialah relevansi. Proksi untuk mengukur kualitas informasi akuntansi dalam penelitian ini adalah relevansi nilai. Penelitian ini akan memberikan gambaran seberapa benefit yang diterima perusahaan saat menerapkan PSAK berbasis IFRS dilihat dari relevansi nilainya. Relevansi nilai adalah kemampuan angka akuntansi untuk mendeskripsikan harga saham perusahaan. Dengan demikian relevansi nilai diukur menggunakan koefisien determinasi $\left(R^{2}\right)$ dari persamaan regresi price model. Mengikuti penelitian sebelumnya, yaitu Kristianto (2015), pengukuran variabel relevansi nilai menggunakan model harga (price model) yang dikembangkan Ohlson (1995), yaitu sebagai berikut:

$P_{i t+1}=\alpha_{0}+\alpha_{1} E P S_{i t}+\alpha_{2} B V E_{i t}+\alpha_{3} O C F_{i t}+e_{i t}$

Keterangan:

$P_{i t+1}=$ Closing price company's share i pada tahun $\mathrm{t}+1$, untuk laporan keuangan tahunan yang diumumkan pada tahun $\mathrm{t}$

t $\quad=$ Tahun 2015 dan 2016

$E P S_{i t}=$ Earnings per share perusahaan i pada tahun $\mathrm{t}$

$B V E_{i t}=$ Book value of equity per share perusahaan i pada tahun $\mathrm{t}$

$O C F_{i t}=$ Operating cash flow per share perusahaan i pada tahun $\mathrm{t}$

$e_{i t} \quad=$ Error

\section{Metode dan Tahapan Analisis}

Metode yang digunakan dalam penelitian ini, yaitu kuantitatif dengan menggunakan teknik analisis statistik dekriptif untuk menjelaskan dan menjawab persoalan serta tujuan yang akan dicapai melalui data-data yang telah ditentukan dalam penelitian ini. Data yang digunakan adalah data sekunder yang diperoleh dari www.idx.co.id dan https://finance.yahoo.com/. Selanjutnya juga dilakukan uji regresi untuk memperoleh koefisien determinasi $\left(R^{2}\right)$ dari persamaan price model.

Berikut ini merupakan tahap untuk menganalisis variabel cost dari penerapan PSAK berbasis IFRS: mengumpulkan laporan keuangan tahunan perusahaan yang terdaftar di BEI pada tahun 2015 dan 2016, membuat skor pembobotan untuk masing-masing akun yang akan diteliti pada tiap-tiap perusahaan, membuat tabulasi bobot skor perusahaan-perusahaan, membuat analisis deskriptif mengenai hasil perhitungan bobot skor cost konvergensi IFRS di Indonesia.

Adapun tahap untuk menganalisis variabel benefit berupa relevansi nilai informasi akuntansi, yaitu sebagai berikut: membuat persamaan regresi price model, menganalisis nilai $\mathrm{R}^{2}$ sebagai indikator relevansi nilai, dan membuat analisis deskriptif atas hasil perhitungan relevansi nilai pada perusahaan-perusahaan publik di Indonesia.

Tahap selanjutnya adalah menganalisis cost-benefit ratio pada perusahaanperusahaan publik di Indonesia dengan formula: 


$$
\frac{\text { nilai rata }- \text { rata cost } \%}{\text { nilai } R^{2} \%}
$$

Rata-rata cost di atas merupakan rerata dari skor upaya atau cost perusahaanperusahaan dalam mengimplementasikan PSAK berbasis IFRS di perusahaannya. Indikator ini akan memberikan perbandingan antara cost (upaya) dan benefit (hasil) yang diperoleh dari penerapan PSAK berbasis IFRS. Analisis cost-benefit ratio akan dibahas berdasarkan ukuran perusahaan dan sektor BEI.

\section{Hasil dan Pembahasan}

Tabel 3 berikut ini merupakan gambaran sampel tahun 2015 dan 2016 yang digunakan dalam penelitian ini.

\section{Tabel 2: Gambaran Sampel}

\begin{tabular}{ccc}
\hline Proses & 2015 & 2016 \\
\hline Jumlah seluruh perusahaan yang terdaftar di BEI & 512 & 528 \\
Penghapusan perusahaan karena tidak terdaftar berturut-turut tahun & & \\
2015-2016 & $(0)$ & $(16)$ \\
Perusahaan terdaftar berturut-turut tahun 2015-2016 & 512 & 512 \\
Penghapusan perusahaan karena data tidak lengkap dalam 2 tahun & $(53)$ & $(53)$ \\
Jumlah perusahaan yang diteliti & 459 & 459 \\
\hline
\end{tabular}

Sumber: Data Penelitian

Penelitian ini menggunakan jenis data sekunder yaitu laporan keuangan tahunan perusahaan yang diperoleh dari website BEI serta closing price saham perusahaan dan jumlah saham yang diperoleh dari Yahoo Finance. Berdasarkan kriteria yang diterapkan, diperoleh 459 perusahaan yang akan diteliti untuk setiap tahun 2015 dan 2016, sehingga diperoleh data penelitian sebanyak 918 untuk menghitung bobot skor cost perusahaan dan untuk menguji relevansi nilai informasi akuntansi perusahaan. Namun, oleh karena adanya transformasi variabel menjadi Ln, maka terdapat beberapa data yang tereleminasi. Berikut hasil analisis deskriptif terhadap jumlah sampel pada Tabel 4 .

\section{Tabel 3: Statistik Deskriptif Jumlah Sampel}

\begin{tabular}{crr}
\hline Ukuran Perusahaan & \multicolumn{2}{c}{ Jumlah Perusahaan } \\
\cline { 2 - 3 } Besar & 2015 & 2016 \\
Kecil & 225 & 234 \\
Sektor BEI & 234 & 225 \\
\hline Pertanian & \multicolumn{2}{c}{20} \\
Pertambangan & \multicolumn{2}{|c}{34} \\
Industri Dasar dan Kimia & \multicolumn{2}{|c}{52} \\
Aneka Industri & \multicolumn{2}{c}{33} \\
Industri Barang Konsumsi & \multicolumn{2}{|c}{30} \\
\hline \multicolumn{2}{c}{54} \\
Properti, Real Estat Dan Konstruksi Bangunan & \multicolumn{2}{c}{50}
\end{tabular}


Pada Tabel 4 diketahui bahwa jumlah perusahaan yang menjadi sampel penelitian berdasarkan kategori ukuran perusahaan besar pada tahun 2015 sebanyak 225 perusahaan dan pada tahun 2016 sebanyak 234 perusahaan sedangkan untuk kategori ukuran perusahaan kecil pada tahun 2015 sebanyak 234 perusahaan dan pada tahun 2016 sebanyak 225 perusahaan. Penentuan ukuran perusahaan tersebut dilihat dari nilai tengah (median) aset perusahaan. Jika nilai aset lebih dari nilai median maka termasuk perusahaan besar begitupun sebaliknya.

Selanjutnya berdasarkan kategori sektor BEI, sektor pertanian sebanyak 20 perusahaan, sektor pertambangan sebanyak 34 perusahaan, sektor industri dasar dan kimia sebanyak 52 perusahaan, sektor aneka industri sebanyak 33 perusahaan, sektor industri barang konsumsi sebanyak 30 perusahaan, sektor properti, real estat dan konstruksi bangunan sebanyak 54 perusahaan, sektor infrastruktur, utilitas dan transportasi sebanyak 50 perusahaan, sektor keuangan sebanyak 80 perusahaan dan sektor perdagangan jasa dan investasi sebanyak 106 perusahaan.

\section{Bobot Cost Implementasi PSAK Berbasis IFRS}

Upaya PSAK yang konvergen terhadap IFRS atau implementasi PSAK berbasis IFRS di tahun 2015 dan 2016 diperhitungkan berdasarkan jumlah PSAK berbasis IFRS yang efektif di tahun tersebut, dimana tiap-tiap implementasi PSAK tersebut memiliki bobot upaya atau pengorbanan yang berbeda-beda. Hal ini tergantung dari kebutuhan implementasinya, apakah hanya memerlukan klasifikasi ulang atau pengakuan ulang atau bahkan sampai pada pengukuran ulang. Adapun statistik deskriptif cost tersaji pada Tabel 5 di bawah ini.

\section{Tabel 4: Statistik Deskriptif Cost}

\begin{tabular}{cccccc}
\hline & & \multicolumn{3}{c}{ Cost } \\
\cline { 4 - 6 } & $\mathrm{N}$ & $\begin{array}{c}\text { Mini } \\
\text { mal }\end{array}$ & $\begin{array}{c}\text { Rata- } \\
\text { rata }\end{array}$ & $\begin{array}{c}\text { Maksim } \\
\text { al }\end{array}$ & $\begin{array}{c}\text { Std. } \\
\text { Deviasi }\end{array}$ \\
\hline Ukuran Perusahaan & & & & & \\
\hline Besar & 459 & 0 & 0,287 & 0,725 & 0,225 \\
Kecil & 459 & 0 & 0,292 & 0,725 & 0,211 \\
\hline Sektor BEI & & & & & \\
\hline Pertanian & 40 & 0 & 0,251 & 0,725 & 0,245 \\
Pertambangan & 68 & 0 & 0,305 & 0,725 & 0,214 \\
Industri Dasar dan Kimia & 104 & 0 & 0,285 & 0,725 & 0,231 \\
Aneka Industri & 66 & 0 & 0,299 & 0,725 & 0,183 \\
Industri Barang Konsumsi & 60 & 0 & 0,285 & 0,725 & 0,227 \\
Properti, Real Estat Dan Konstruksi & 108 & 0 & 0,329 & 0,725 & 0,232 \\
Bangunan & 100 & 0 & 0,290 & 0,725 & 0,237
\end{tabular}




\begin{tabular}{clllll} 
Keuangan & 160 & 0 & 0,289 & 0,725 & 0,209 \\
Perdagangan Jasa Dan Investasi & 212 & 0 & 0,272 & 0,725 & 0,207 \\
\hline Total Sampel & 918 & & & \\
\hline
\end{tabular}

Sumber: Hasil Pengolahan Data Sekunder

Berdasarkan Tabel 5 diketahui bahwa nilai maksimal sebesar 72,5\% di setiap kategori, yang artinya dalam berbagai kategori skor effort atau upaya untuk implementasi PSAK dinilai sebesar 72,5\%. Hal tersebut dikarenakan adanya penearapan PSAK 53, PSAK 22, PSAK 46, PSAK 24, PSAK 19, PSAK 16, PSAK 50/PSAK 55, PSAK 13 dan PSAK 15. Nilai minimal di tiap kategori adalah 0, hal ini menandakan bahwa terdapat perusahaan yang sama sekali tidak menerapkan PSAK yang efektif di tahun 2015 dan 2016. Sektor Properti, Real Estat dan Konstruksi Bangunan secara rata-rata memiliki effort atau upaya untuk implementasi PSAK paling tinggi sebesar $32,9 \%$, karena pada sektor ini banyak menerapkan PSAK 50/PSAK 55, PSAK 53, PSAK 22, PSAK 13 yang memiliki bobot skor besar.

Adapun sektor Pertanian secara rata-rata memiliki effort atau upaya untuk implementasi PSAK paling rendah sebesar 25,1\%, karena pada sektor ini jarang menerapkan PSAK 50/ PSAK 55, PSAK 53, PSAK 22 dan PSAK 13 yang memiliki bobot skor besar, serta PSAK 46, PSAK 24 dan PSAK 19.

Tabel 6: Sebaran Implementasi berdasarkan PSAK

\begin{tabular}{ccc}
\hline & \multicolumn{2}{c}{ Tahun } \\
\cline { 2 - 3 } PSAK & 2015 & 2016 \\
\hline 53 & 108 & 142 \\
22 & 108 & 167 \\
8 & 0 & 0 \\
46 & 429 & 98 \\
3 & 1 & 0 \\
24 & 444 & 314 \\
1 & 0 & 0 \\
19 & 108 & 211 \\
16 & 108 & 283 \\
50,55 & 408 & 2 \\
13 & 105 & 148 \\
15 & 305 & 205 \\
14 & 0 & 0 \\
2 & 0 & 93 \\
26 & 0 & 0 \\
57 & 0 & 2 \\
\hline
\end{tabular}

Berdasarkan Tabel 6 di atas diketahui bahwa pengorbanan perusahaan-perusahaan paling banyak terjadi karena implementasi PSAK 15, PSAK 24, PSAK 46, PSAK 50 dan 55 di tahun 2015 dan PSAK 24 di tahun 2016. 


\section{Relevansi Informasi Akuntansi Setelah Implementasi PSAK Berbasis IFRS}

Relevansi informasi akuntansi diindikasikan melalui kemampuan penjelas dari angka-angka akuntansi (EPS, BVE, OCF) terhadap harga saham. Kemampuan penjelas ini diperoleh dari koefisien determinasi $\left(\mathrm{R}^{2}\right)$ dari fungsi regresi variabel dependen (EPS, BVE dan OCF) terhadap harga saham. Uji regresi berganda dalam penelitian telah lolos pengujian asumsi klasik, yaitu uji normalitas, uji heteroskedastisitas, uji multikolinearitas dan uji autokorelasi. Seluruh model penelitian lolos uji asumsi klasik. Hasil tersebut dapat dilihat selengkapnya di lampiran. Hasil pengukuran relevansi nilai informasi yang dilakukan dalam penelitian ini dapat dilihat pada Tabel 7.

Tabel 7: Hasil Analisis Regresi Berganda

\begin{tabular}{|c|c|c|c|c|c|c|c|c|c|}
\hline & \multirow[b]{2}{*}{$\mathrm{N}$} & \multicolumn{2}{|c|}{ EPS } & \multirow{2}{*}{$\begin{array}{l}\text { BVE } \\
\text { Koefi } \\
\text { sien } \\
\end{array}$} & \multicolumn{2}{|c|}{$\mathrm{OCF}$} & $R^{2}$ & \multicolumn{2}{|c|}{ Sig } \\
\hline & & $\begin{array}{c}\text { Koefi } \\
\text { sien }\end{array}$ & Sig & & Sig & $\begin{array}{c}\text { Koefis } \\
\text { ien }\end{array}$ & Sig & & \\
\hline $\begin{array}{c}\text { Ukuran } \\
\text { Perusahaan }\end{array}$ & & & & & & & & & \\
\hline Besar & 459 & 0,78 & 0,00 & 0,00 & 0,88 & 0,06 & 0,04 & 0,63 & 0,00 \\
\hline Kecil & 459 & 0,08 & 0,06 & 0,01 & 0,81 & 0,06 & 0,15 & 0,01 & 0,05 \\
\hline Sektor BEI & & & & & & & & & \\
\hline Pertanian & 40 & 0,61 & 0,04 & 0,34 & 0,29 & 0,45 & 0,04 & 0,35 & 0,03 \\
\hline Pertambangan & 68 & 0,48 & 0,01 & 0,04 & 0,80 & $-0,08$ & 0,75 & 0,16 & 0,00 \\
\hline $\begin{array}{c}\text { Industri Dasar } \\
\text { dan Kimia }\end{array}$ & 104 & 0,62 & 0,00 & 0,04 & 0,83 & 0,05 & 0,75 & 0,50 & 0,00 \\
\hline Aneka Industri & 66 & 0,63 & 0,00 & 0,71 & 0,09 & $-0,42$ & 0,31 & 0,55 & 0,00 \\
\hline $\begin{array}{c}\text { Industri Barang } \\
\text { Konsumsi }\end{array}$ & 60 & 0,78 & 0,00 & 0,07 & 0,52 & 0,06 & 0,50 & 0,72 & 0,00 \\
\hline $\begin{array}{l}\text { Properti, Real } \\
\text { Estat Dan } \\
\text { Konstruksi } \\
\text { Bangunan }\end{array}$ & 108 & 0,83 & 0,00 & 0,03 & 0,51 & $-0,01$ & 0,86 & 0,69 & 0,00 \\
\hline $\begin{array}{c}\text { Infrastruktur, } \\
\text { Utilitas Dan } \\
\text { Transportasi }\end{array}$ & 100 & 0,55 & 0,00 & 0,22 & 0,58 & 0,39 & 0,32 & 0,38 & 0,00 \\
\hline Keuangan & 160 & 0,55 & 0,00 & 0,39 & 0,00 & 0,01 & 0,78 & 0,74 & 0,00 \\
\hline $\begin{array}{c}\text { Perdagangan } \\
\text { Jasa Dan } \\
\text { Investasi } \\
\end{array}$ & 212 & 0,11 & 0,07 & 0,36 & 0,00 & 0,22 & 0,02 & 0,39 & 0,00 \\
\hline Total Sampel & 918 & & & & & & & & \\
\hline
\end{tabular}

Sumber : Output Pengolahan Data Statistik dengan SPSS (2018)

Berdasarkan Tabel 7 diketahui untuk ukuran perusahaan besar memiliki nilai signifikansi dalam uji F lebih kecil dari 0,05 sehingga EPS, BVE dan OFC berpengaruh signifikan terhadap harga saham (P), serta memiliki nilai $\mathrm{R}^{2}$ sebesar 0,632 , yang artinya EPS, BVE dan OCF mampu menjelaskan harga saham (P) sebanyak 63,2\% sedangkan sisanya 36,8\% dijelaskan oleh faktor lain di luar model. Pada ukuran perusahaan kecil memiliki nilai signifikansi dalam uji $\mathrm{F}$ lebih besar dari 0,05, yaitu sebesar 0,059 sehingga secara bersama-sama EPS, BVE dan OCF tidak berpengaruh 
signifikan terhadap harga saham (P). Demikian pula secara individual, masing-masing informasi akuntansi tidak mampu menjelaskan harga saham, atau dikatakan tidak memiliki relevansi nilai informasi.

Implementasi PSAK berbasis IFRS pada perusahaan kecil tampak lebih besar dibandingkan pada perusahaan besar, dimana informasi akuntansi pada perusahaan kecil setelah implementasi PSAK dinilai lebih relevan. Adapun apabila dilihat berdasarkan kelompok industrinya, perusahan pada sektor pertanian dan pertambangan lebih memperoleh manfaat dari implementasi PSAK berbasis IFRS dibanding perusahaan pada sektor lainnya.

\section{Pembahasan}

Selanjutnya untuk menilai seberapa efektif upaya/pengorbanan perusahaan dalam mengimplementasikan PSAK berbasis IFRS dalam menghasilkan informasi akuntansi yang relevan, maka dilakukan pembandingan antara cost dan benefit implementasi PSAK tersebut. Tabel 8 berikut ini menyajikan cost-benefit ratio implementasi PSAK berbasis IFRS untuk tiap-tiap kategori perusahaan berdasarkan ukuran maupun sektor industrinya.

Tabel 8: Hasil Cost-Benefit Ratio

\begin{tabular}{ccc}
\hline & $\mathrm{N}$ & ${ }^{*}$ Cost-Benefit Ratio \\
\hline Ukuran Perusahaan & & \\
\hline Besar & 459 & 0,45 \\
Kecil & 459 & 18,25 \\
\hline Sektor BEI & & \\
\hline Pertanian & 40 & 0,70 \\
Pertambangan & 68 & 1,82 \\
Industri Dasar dan Kimia & 104 & 0,56 \\
Aneka Industri & 66 & 0,54 \\
Industri Barang Konsumsi & 60 & 0,39 \\
Properti, Real Estat Dan Konstruksi Bangunan & 108 & 0,48 \\
Infrastruktur, Utilitas Dan Transportasi & 100 & 0,76 \\
Keuangan & 160 & 0,39 \\
Perdagangan Jasa Dan Investasi & 212 & 0,69 \\
\hline
\end{tabular}

*nilai rata-rata cost $\%$

nilai $R^{2} \%$

Sumber: Hasil Pengolahan Data Sekunder

Di Indonesia, konvergensi IFRS merupakan penyesuaian PSAK terhadap IFRS. Proses penyesuaian tersebut membutuhkan cost, sekaligus juga diharapkan dapat memberikan benefit yang lebih besar dari cost yang ditanggung. Berdasarkan Tabel 8, jika nilai cost-benefit ratio kurang dari 1, berarti benefit yang dihasilkan dari konvergensi IFRS lebih besar dari cost yang dikeluarkan. Semakin kecil nilai costbenefit ratio menunjukkan cost atau upaya yang dikeluarkan lebih kecil dibandingkan 
dengan benefit atau manfaat yang diterima perusahaan saat PSAK berbasis IFRS diimplementasikan.

Pada ukuran perusahaan besar, nilai cost-benefit ratio sebesar 0,45 $(<1)$ yang didapat dari perbandingan antara nilai rata-rata cost sebesar $28,7 \%$ dan nilai $\mathrm{R}^{2}$ sebesar $63,2 \%$. Hal tersebut menunjukan cost atau upaya yang dikeluarkan lebih kecil dibandingkan dengan benefit atau manfaat yang diterima perusahaan saat PSAK berbasis IFRS diimplementasikan. Beda halnya dengan ukuran perusahaan kecil, costbenefit rasio bernilai sangat tinggi, karena besarnya relevansi informasinya sangat kecil yang berarti pengaruh informasi akuntansi terhadap harga saham tidak signifikan. Hal ini kemungkinan terjadi karena investor lebih berfokus pada perusahaan ukuran besar (Jalil 2013).

Sektor Industri Barang Konsumsi dan sektor Keuangan yang sama-sama memiliki nilai cost-benefit ratio 0,39 , serta menjadi sektor dengan nilai paling kecil. Untuk sektor Industri Barang Konsumsi, nilai tersebut didapat dari perbandingan antara nilai rata-rata cost sebesar $28,5 \%$ dan nilai $\mathrm{R}^{2}$ sebesar $72,9 \%$. Adapun untuk sektor Keuangan, nilai didapat dari perbandingan antara nilai rata-rata cost sebesar 28,9\% dan nilai $\mathrm{R}^{2}$ sebesar $74,9 \%$. Hal tersebut menunjukan cost atau upaya yang dikeluarkan lebih kecil dibandingkan dengan benefit atau manfaat yang diterima perusahaan saat PSAK berbasis IFRS diimplementasikan. Pada kedua sektor ini, rendahnya cost-benefit ratio terutama disebabkan oleh tingginya nilai relevansi informasi akuntansi. Tingginya relevansi nilai informasi akuntansi, dapat terkait oleh fakta bahwa pada perusahaan sektor Industri Barang Konsumsi banyak terdapat saham blue chip dan LQ45 dan 73\% perusahaan pada sektor Keuangan merupakan perusahaan dengan kategori ukuran besar.

Beda halnya dengan sektor Pertambangan nilai cost-benefit rasio sebesar 1,82 (>) yang didapat dari perbandingan antara nilai rata-rata cost sebesar 30,5\% dan nilai $\mathrm{R}^{2}$ sebesar $16,8 \%$. Hal tersebut menunjukan cost atau upaya yang dikeluarkan lebih kecil dibandingkan dengan benefit atau manfaat yang diterima perusahaan saat PSAK berbasis IFRS diimplementasikan. Selain karena tingginya cost implementasi PSAK di tahun 2015-2016, relevansi informasi akuntansi di sektor pertambangan juga relatif rendah. Tingginya cost implementasi karena banyaknya perusahaan yang menerapkan PSAK 50/PSAK 55, PSAK 22 dan PSAK 19 dengan bobot skor tinggi. Rendahnya relevansi nilai informasi akuntansi, dapat tekait oleh fakta bahwa $78 \%$ perusahaan sektor Pertambangan adalah perusahaan dengan kategori ukuran kecil.

Secara umum nilai cost-benefit ratio menunjukkan bahwa manfaat dari implementasi PSAK berbasis IFRS masih lebih tinggi dibandingkan pengorbanan yang dikeluarkan atau cost. Hanya sebagian kecil kelompok perusahaan yang ditemukan bahwa pengorbanan atau cost penerapan PSAK tidak sebanding dengan manfaatnya atau benefit, yaitu pada perusahaan berskala kecil dan perusahaan pada sektor Pertambangan. Hal ini dapat dimaknai bahwa secara umum, penerapan PSAK berbasis IFRS memiliki manfaat positif bagi berbagai pemangku kepentingan. Bagi pasar, kualitas informasi akuntansi dinilai baik. Adapun dari sudut pandang 
perusahaan, pengorbanan penerapan PSAK berbasis IFRS masih lebih rendah dari manfaat yang diperoleh.

Pada dasarnya hasil analisis dan pembahasan dapat disajikan dalam sub-bagian yang berbeda, atau dalam sub-bagian yang sama dengan topik tertentu. Berikut ini contoh pembahasan yang disajikan terpisah dari hasil analisis. Hasil uji hipotesis menunjukkan variabel kinerja lingkungan berpengaruh positif signifikan terhadap kualitas pengungkapan lingkungan dengan tingkat signifikansi $5 \%\left(0,0022<0,05, \mathrm{H}_{1}\right.$ diterima). Berdasarkan hasil tersebut, dapat dikatakan perusahaan yang memunyai kinerja lingkungan baik akan memunyai pengungkapan lingkungan yang semakin berkualitas. Hal tersebut dilakukan sebagai upaya dalam membedakan diri dari perusahaan yang memiliki kinerja lingkungan yang buruk. Pelaku lingkungan yang baik percaya bahwa dengan mengungkapkan kinerja lingkungan mereka akan memberikan keuntungan bagi perusahaan (Aulia \& Agustina, 2015).

\section{Simpulan}

Berdasarkan hasil penelitian yang telah dilakukan, dapat disimpulkan bahwa pada perusahaan ukuran besar nilai cost-benefit ratio kurang dari 1 yang menunjukan bahwa cost lebih kecil dari benefit. Sedangkan pada perusahaan ukuran kecil, costbenefit rasio bernilai sangat tinggi, karena besarnya relevansi informasinya sangat kecil yang menunjukkan bahwa pengaruh informasi akuntansi terhadap harga saham tidak signifikan. Adapun nilai cost-benefit ratio terendah terdapat pada sektor Industri Barang Konsumsi dan sektor Keuangan, karena tingginya nilai relevansi informasi akuntansi. Sedangkan nilai cost-benefit ratio tertinggi terdapat pada sektor Pertambangan karena tingginya cost implementasi PSAK di tahun 2015-2016, relevansi informasi akuntansi di sektor pertambangan juga relatif rendah.

Penelitian ini secara umum membuktikan bahwa secara bertahap implementasi PSAK berbasis IFRS terdapat relevansi nilai informasi akuntansi berupa EPS, BVE dan OFC terhadap harga saham konsisten dengan penelitian Kristanto (2015), serta Suprihatin dan Tresnaingsih (2013). Sudah ada penelitian yang membahas tentang cost-benefit dari konvergensi IFRS tetapi penelitian tersebut membandingkan cost negara Inggris, Hongkong dan Singapura serta benefit negara Inggris, Hongkong dan Singapura (Taylor 2009). Sehingga penelitian kali ini memberikan tambahan perspektif perbandingan antara cost atau pengorbanan dengan benefit atau manfaat di satu negara, yaitu Indonesia.

Penelitian ini memiliki keterbatasan pada dimensi dengan benefit yang berupa relevansi nilai, yang sebenarnya masih banyak dimensi-dimensi lain seperti manajemen laba, timely recognition dan predictability. Oleh karenanya saran bagi penelitian berikut agar mengunakan dimensi-dimensi lain. Penelitian ini juga memiliki keterbatasan pada skor cost yang bersifat relatif antara satu kelompok dengan yang lain atau bukan skor absolut serta cost hanya terbatas pada tahun 2015 dan 2016. Penelitian berikutnya disarankan untuk menilai cost-benefit dengan 
rentang waktu yang lebih panjang, sehingga upaya konvergensi berbagai PSAK revisi terbaru berdasarkan IFRS dapat dilihat lebih komprehensif.

\section{Daftar Pustaka}

Albari. (2009). Pengaruh Kualitas Layanan Terhadap Kepatuhan Membayar Pajak. Jurnal Siasat Bisnis, 1-13.

Awaluddin, I., \& Tamburaka, S. (2017). The Effect of Service Quality and Taxpayer Satisfaction on Compliance Payment Tax Motor Vehicles at Office One Roof System in Kendari. The International Journal of Engineering and Science, 6(11), 2319 - 1805.

Cahyati, A. D. (2011). Peluang Manajemen Laba Pasca Konvergensi IFRS: Sebuah Tinjauan Teoritis dan Empiris. Jurnal F. Ekonomi: JRAK, 2, 1-7.

Cahyonowati, N., \& Ratmono, D. (2012). Adopsi IFRS dan Relevansi Nilai Informasi Akuntansi. Jurnal Akuntansi dan Keuangan, Vol. 14, No. 2, 105-115.

Direktorat Jendral Pajak. (2008). Modernisasi Administrasi Perpajakan:Laporan Tahunan 2007. Jakarta: Departemen Keuangan Republik Indonesia.

Enni Savitri, M. (2016). The Effect of Taxpayer Awareness, Tax Socialization, Tax Penalties, Compliance Cost at Taxpayer Compliance with Service Quality as Mediating Variable. Social and Behavioral Sciences, 219, 682-687.

Fasmi, L., \& Misra, F. (2014). Modernisasi Sistem Administrasi Perpajakan dan Tingkat Kepatuhan Pengusaha Kena Pajak. Jurnal Akuntansi Multiparadigma, 5(1), 76-87.

Feld, L. P., \& Frey, B. S. (2002). Trust Breeds Trust: How Taxpayers are Treated Working Paper No. 98. Zurich: Institute For Empiricial Research in Economics University of Zurich.

Frecknall-Hughes, J., \& Moizer, P. (2015). Assessing the quality of services provided by UK tax practitioners. eJournal of Tax Research, 13(1), 51-75.

Gasperzs, V. (1997). Manajemen Kualitas : Penerapan Konsep Kualitas Dalam Manajemen Bisnis Total. Jakarta: Gramedia.

Ikatan Akuntan Indonesia. (2017). Standar Akuntansi Keuangan. Retrieved November 19, 2017, from http://iaiglobal.or.id/v03/standar-akuntansi-keuangan/sak

Irena, F. (2014). Faktor-faktor yang Mempengaruhi Kepatuhan Wajib Pajak Orang Pribadi yang Melakukan Kegiatan Usaha di Pasar Kapasan Surabaya. Retrieved Mei 20, 2017, from http://repository.wima.ac.id 
Jalil, R. (2013). Pengaruh Persistensi Laba, Growth Opportunities, Dan Ukuran Perusahaan Terhadap Relevansi Nilai Laba Akuntansi (Studi Empiris Pada Perusahaan Manufaktur Yang Terdaftar Di PT. BEI). Jurnal Akuntansi, 1-29.

Jaya, A., Ratnawati, T., \& Sardjono, S. (2017). Analysis of Effect of Knowledge and Service Quality, Accessibility of Information, Awareness and Behavior of Taxpayers and Impact on Satisfaction and Compliance With Taxpayers of Land and Buildings in The City Batam Island Riau Province. International Journal of Business and Management Invention, 6(8), 73-83.

Juanda, A. (2014). Kandungan Prinsip Konservatisme dalam Standar Akuntansi Keuangan Berbasis IFRS (International Financial Reporting Standard). Jurnal Humanity, Vol. 7, No. 2, 24-34.

Kargin, S. (2013). The Impact of IFRS on the Value Relevance of Accounting Information: Evidence from Turkish Firms. International Journal of Economics and Finance, Vol. 5, No. 4, 71-80.

Kotler, P. (2003). Manajemen Pemasaran (Milenium ed.). (H. Teguh, R. Rusli, \& B. Molan, Trans.) Jakarta: PT Prenhallindo.

Kristanto, A. B. (2015). Does IFRS Convergence Promote the Value Relevance of Accounting Information? Jurnal Eknomika dan Bisnis, Vol. XVIII, No. 1, 19-40.

Lestari, Y. O. (2013). Konvergensi International Financial Reporting Standards (IFRS) dan Manajemen Laba di Indonesia. El Muhasaba: Jurnal Akuntansi, 2.

Mustaphaa, B., \& Obid, S. N. (2014). Tax Service Quality: The Mediating Effect of Perceived Ease of Use of the Online Tax System. Procedia - Social and Behavioral Sciences, 2-9.

Nurhayati, N., Halimatusadiah, E., \& Diamonalisa. (2015). Influence of tax officer service quality and knowledge of tax on individual taxpayer compliance in tax office (KPP) Bojonagara Bandung. International Journal of Applied Research, 1(8), 805-809.

Qomariah, R. N., \& Marsono. (2013). Dampak Konvergensi IFRS terhadap Manajemen Laba dengan Struktur Kepemilikan Manajerial sebagai Variabel Moderating (Studi Empiris pada Perusahaan Manufaktur yang Terdaftar di Bursa Efek Indonesia Tahun 20092012). 1-11.

Silalahi, S., Musadieq, M. A., \& Nurtjahjono, G. E. (2015). Pengaruh Kualitas Pelayanan Perpajakan Terhadap Kepuasan Wajib Pajak, Kepatuhan Wajib Pajak dan Penerimaan Pajak. Jurnal Perpajakan (JEJAK).

Sugiarti. (2017). Adopsi Penuh Harmonisasi Standar Akuntansi. Ekonomi Bisnis dan Kewirausahaan, Vol. 5, No. 2, 178-201.

Supadmi, N. L. (2009). Meningkatkan Kepatuhan Wajib Pajak Melalui Kualitas Pelayanan. Retrieved Mei 15, 2017, from http://jurnal.pdii.lipi.go.id 
Suprihatin, S., \& Tresnaningsih, E. (2013). Dampak Konvergensi International Financial Reporting Standards Terhadap Nilai Relevan Informasi Akuntansi. Akuntansi dan Keuangan Indonesia, 10, 171-183.

Sutopo, \& Suryanto, A. (2003). Pelayanan Prima. Jakarta: LAN-RI.

Taylor, D. W. (2009). Cost-benefits of Adoption of IFRSs in Countries with Different Harmonization Histories. Asian Review of Accounting, Vol. 17(1), 40-58.

Tenenhaus, M., Vinzi, V. E., Chatelin, Y.-M., \& Lauro, C. (2005). PLS Path Modeling. Computational Statistics \& Data Analysis, 48, 159-205.

Tjiptono, F. (2007). Pemasaran Jasa. Malang: Bayumedia Publishing.

Utami, W. (2006). Analisis Determinan Audit Delay Kajian Empiris di Bursa Efek Jakarta. Bulletin penelitian, Vol. 9, 19-32.

Utami, W. D., Suhardjanto, D., \& Hartoko, S. (2012). Investigasi Dalam Konvergensi IFRS di Indonesia: Tingkat Kepatuhan Pengungkapan Wajib dan Kaitannya dengan Mekanisme Corporate Governance. Simposium Nasional Akuntansi XV Banjarmasin, $0-27$.

Walsh, K. (2012). Understanding Taxpayer Behaviour -New Opportunities for Tax Administration. The Economic and Social Review, 43(3).

Wibowo, S. B. (2012). Analisis Estimasi Cost-Volume-Profit (CVP) dalam Hubungannya dengan Perencanaan Laba Pada Hotel Tlogo Mas Sarangan. Assets: Jurnal Akuntansi dan Pendidikan, Vol. 1, No. 1, 13-23.

Worsham, J., \& Ronald, G. (2006). The Effect of Tax Authority Behavioron Tax Payer Compliance: A Procedural Justice Approach. Journal of American Taxation, 18(2), 1939.

Zeithaml, Valarie, A., Berry, P. d., \& Leonard. (2003). Delivering Quality Service Balancing Costumer Perceptions and Expectations. New York: The Free Press A Division of Mac Milan, Inc. 